\title{
Influence of Cost Leadership Strategy on Performance of Deposit Taking Savings and Credit Cooperative Societies in Uasin Gishu County, Kenya
}

\author{
Mr. Peter Simotwo ${ }^{1 *}$, Dr. Phelista Wangui Njeru², Dr. Christine Jeptoo ${ }^{2} \&$ Dr. Erastus Thoronjo ${ }^{3}$ \\ 1.Scholar, School of Business and Economics, Mount Kenya University \\ 2.Doctor, School of Business and Economics, Mount Kenya University \\ 3.Senior Lecturer, School of Business and Economics, Mount Kenya University \\ * E-mail of the corresponding author: petersimotwo532@gmail.com
}

\begin{abstract}
Savings and Credit Co-operative Societies (SACCOs) in Kenya quite like any other commercial establishments encounter significant difficulties that are presented by ever-changing and intensely aggressive market conditions. Nevertheless, for SACCOs to contest confidently and remain relevant and competitive, they are obliged to recognize and follow relevant competitive strategies as a fundamental determinant for exceptional performance. This study analyzed the influence of cost leadership strategy on performance of deposit-taking SACCOs at branch network level in Uasin Gishu County. Porter Generic Strategies Model guided this study. For the accomplishment of the study objective, it was crucial to analyze the relationship between different variables connected with the research in relation to the performance of deposit-taking SACCOs hence positivism philosophy and cross-sectional descriptive survey research design were employed. Target population consisted of 277 officials from the deposittaking SACCOs. Yamane (1967) formula employed to determine expected sample size of 164 participants. A fivepoint Likert scale questionnaire was adopted for primary data collection. Reliability of the instruments was resolved through the internal consistency where Cronbach's Alpha correlation coefficient of 0.7 and above was considered acceptable. Data were descriptively analyzed using means and standard deviations, and inferentially by correlation and regression analysis to measure strength and direction before fitting the Multiple Linear Regression model. The study found that there is a statistically significant positive influence of constructs of cost leadership strategy $(\mathrm{p}<0.05 ; \mathrm{R} 2=0.678)$ hence the study rejected the null hypothesis. The study therefore concluded that there was a statistically significant influence of cost leadership strategy on performance of deposittaking SACCOs and therefore, recommended that deposit-taking SACCOs in Uasin Gishu County should devise cost leadership strategy for wide markets using cheap sourcing, reduced operational costs and economies of scale to achieve superior performance.
\end{abstract}

Keywords: Cost Leadership Strategy deposit-taking SACCOs’ performance, Uasin Gishu, Kenya

DOI: $10.7176 / \mathrm{EJBM} / 13-20-01$

Publication date:October $31^{\text {st }} 2021$

\section{Acknowledgement}

First, I am indebted to the Almighty God for giving me life and patience to pursue this study. Two, i wish to communicate my genuine appreciation to my principal supervisors, Dr. Phelista Wangui Njeru, Dr. Christine Jeptoo and Dr. Erastus Thoronjo for their professional direction, support, constant reassurance, and friendly assistance during the development of this thesis. To my precious family, thank you for your constant prayers and financial support. May God bless you all.

\subsection{Background of the Study}

In cooperative movements, intensified competition frightens the attractiveness of the movement and lessens its superior performance. This exerts pressure on cooperatives to be proactive and to formulate flourishing competitive strategies that take pleasure of strengths and opportunities, overcome, or neutralize weaknesses and threats (Johnson \& Scholes, 2012). Escalated competition between SACCOs, commercial banks, and microfinance institutions (MFI) has intensified the rate of rivalry. This frictionless commerce tends to raise customers' expectations about products and services and makes them more susceptible to switching from one service provider to the other hence weakening the active membership of an organization (Barney, 2011). Most successful organizations have strategies that are concerned with their particular environment, which offers a strong competitive advantage. Though business situations are different; there is no strategy that is best fit for all companies (Allen \& Helms, 2006), however, a firm adopts the strategy that satisfies it fully and then proceeds forward to pursue it.

SACCOs, therefore, aim at achieving a competitive edge to permit them to acknowledge and contend productively in the market. Cost leadership strategy is one of the key strategies for the continuation, expansion, and growth of any enterprise and more so in extremely competitive industries such as the financial sector (Sumer 
\& Bayraktar, 2012). Cost leadership is based on a firm exceeding its competitors through lessening the cost of inputs along the supply chain, which it expects to be reflected in the pricing of its services.

The goal of cost leadership is for a company to become the lowest-cost competitor in its industry (Achieng' \& Ngala, 2019). A low-cost manufacturer often creates and exploits all areas of cost advantage. The notion is that if a company achieves and sustains overall cost leadership, it will have performance that is above average in its industry as long as it can command prices that are within the industry average (Porter, 2012). The sources of cost advantage vary depending on the industry structure. When adopting a low-cost strategy, a business should prioritize resources that help in efficiency. A firm that has effectively built a low-cost position will have the lowest expenses compared to competitors (Gure \& Karugu, 2018). A firm may take advantage of this situation by either lowering its prices or gaining market share and sales from competitors, or by maintaining its prices at current market levels and generating a larger profit per unit sold. (Porter, 1990)

The key point in cost leadership is that cost and pricing are distinct decisions, and this method is cost-driven (Karabulut, 2015). They may include, among other things, the pursuance of economies of scale, established technology, furnished access to raw resources, and other reasons. A low-cost firm must recognize and benefit from all fields of cost-benefit. If a firm can accomplish and manage total cost leadership, it will be an above-average performer in its industry, as long as it can charge prices that are at or near the industry average.Overall, cost leadership necessitates organizations developing strategies targeted at becoming and being the industry's lowestcost producer and/or distributor while focusing on enhanced performance.

\subsection{Statement of the Problem}

SACCOs execute a significant role in the mobilization of resources and therefore the sub-sector holds a strategic position in the social-economic growth and the fulfillment of the Kenya Vision 2030. However, DT-SACCOs have continued to face problems despite their significant contribution to the economy especially in the recent performance trends. SASRA (2017) supervision report showed a static membership share at 3.6 Million persons in 2017 as it was in 2016 and 2015. The dormant membership is an evidence of stagnation in membership. The distribution of the market share by way of the total assets held by DT-SACCOs remained the same in 2017 as it was in 2016 and 2015; the combined total assets portfolio declined from $35.02 \%$ in $2015,35.36 \%$ in 2016 to $32.38 \%$ in 2017. The SACCOs paid an average $6.95 \%$ interest on members' deposits (savings) which was a marked decrease from the average rate of $9.7 \%$ paid in 2016 and 2015 which reflected a decrease from the average rate of $8.58 \%$ paid in $2015,8.4 \%$ paid in 2016 . Total deposits in 2017 stood at $12.4 \%, 11.3 \%$ and $12 \%$ respectively, compared to $14.8 \%, 15.3 \%$, and $14.8 \%$ respectively registered in 2016 and 2015 .

Using multiple regressions analysis on quantitative data Achieng and Ngala (2019) revealed that product differentiation and cost leadership strategy have a joint significant effect on performance of small and medium enterprises within Nakuru. Buul and Omundi (2017) who employed a descriptive correlation design found that cost leadership, differentiation, market focus and strategic alliance were all found to have a positive and significant influence on SME performance. However, Justinian (2015) on using Chi-square tests and linear regression confirmed that there is insignificant relationship between the Porter strategies and firm performance of Zanzibar Hotel Industry. Mandara (2014), who used cross-sectional survey on secondary data, demonstrated that adoption of Broad Hybrid, Hybrid Differentiation, Hybrid Mentor and Peer differentiation strategies corresponded to better performance of MSEs.

Onyonyi (2018) intended to extend the generalization ability of Ansoff's growth strategies to formulating relevant policy frameworks for guiding the growth of SMEs using cross sectional survey research design and found that growth of SMEs was due to generic competitive strategies applied. The reviewed empirical studies attest to the fact that different combinations of generic strategies (constructs) as indicators of performance among various industries and in different countries; using different methodologies. More so, the results are depicting mixed (different findings). Nevertheless, among these studies, there is scanty literature; empirical and theoretical, on the most suited combination of generic competitive strategies for enhancing performance of DT-SACCOs. Thus, there is insufficiency of empirical on the influence of cost leadership strategy on performance of DT-SACCOs in Uasin Gishu County.

Therefore, the applicability of the Porters generic strategies on performance of performance of DT-SACCOs is yet to be empirically established, a knowledge gap this research sought to lock. The researcher acknowledged also the need for empirical gaps to recognize a framework, which extends itself to strategic competitiveness. Methodological gaps were also recognized firmly that there was need for more objective indicators of performance, because it fell short in most of the previous studies. In order to promote growth of knowledge in this important area, the researcher purposed to study on the cost leadership strategy and performance of DT-SACCOs in Uasin Gishu County, Kenya.

\subsection{Objective of the Study}

The main objective of study was to analyze the influence of cost leadership strategy on performance of deposit 
taking SACCOs in Uasin Gishu County, Kenya.

\subsection{Hypotheses}

$\mathbf{H}_{01}$ : There is no statistically significant influence between cost leadership strategy and performance of deposittaking SACCOs in Uasin Gishu County, Kenya.

\subsection{Theoretical Review}

\subsubsection{Porter Generic Strategies Model}

Michael Porter proposed this concept, Porter's generic strategies, which illustrates how a business seeks a competitive edge throughout the market scope in 1980 (Porter, 1998). Cost leadership, differentiation, cost focus, or focus differentiation are the four general strategies (Porter, 2007). A firm may pursue one of two forms of competitive advantage: lower expenses than its competitors or distinguishing itself along dimensions desired by consumers in order to charge a higher price (Porter \& Kramer, 2011). A firm can also choose between two sorts of scope: focus (providing its products to certain market groups) or industry-wide (Porter, 2012).

The generic strategy reflects the decisions taken in terms of both the type and extent of competitive advantage. Porter's generic competitive strategies may be used to determine strategic positions at both the simple and wide levels of an organization (Porter \& Kramer, 2011). The industrial structure and placement within the business served as the foundation for Porter's model. These strategies were cost leadership and distinctiveness, with the third strategy, focus, based on the first two. The firm's competitive breadth is determined by its focus. This scope differentiates between businesses concentrating on large industry segments and firms focusing on specific industry segments.

Cost leadership strategy enables the business to be a low-cost provider, earning greater profits than competitors due to lower manufacturing costs and economies of scale. They often focus on being the lowest-cost provider in an industry for a certain level of quality, and then offer these items either at the average industry price to generate larger profits than competitors, or at rates below the average price to win or increase market share. These businesses take advantage of their cheap manufacturing costs to sell at below average pricing (Porter, 1998). In the event of a pricing war, such businesses can sustain profitability while their competitors continue to lose money.

In summary, Porter contends that businesses can succeed in implementing numerous strategies by establishing different business units for each of the aforementioned strategies, because buyers frequently seek multidimensional aspects of a product to gain maximum usefulness (Barney, 2007). This theory was found useful in building the cost leadership that was likely to steer the competitiveness and performance of DT-SACCOs. Therefore, the model is appropriate in this study because, with the right identification and acceptance of cost leadership constructs, deposit-taking SACCOs will be in a position to influence the industry forces hence attaining superior performance.

\subsection{Conceptual Framework}

In this research, the study concept was informed by Porter's generic strategies model (Porter, 1998) which stipulates that there are four strategies; cost leadership, differentiated, focus cost, or focus differentiated for driving performance of a firm through gaining the competitive edge. In seeking to establish the applicability of this theory, this study adopted cost leadership, and performance of deposit-taking SACCOs as its key constructs. In this, case, cost leadership strategy is the independent variable while performance of deposit-taking SACCOs are dependent variable as revealed in figure 1 .

Independent Variable

Dependent Variable

\begin{tabular}{|c|c|}
\hline $\begin{array}{l}\text { Cost Leadership Strategy } \\
\text { - } \quad \text { Cheap Sourcing } \\
\text { - } \quad \text { Reduced Operational Costs } \\
\text { - } \\
\text { Economies of Scale }\end{array}$ & $\begin{array}{c}\text { DT-SACCOs Performance } \\
\text { - Membership } \\
\text { - } \quad \text { Profitability } \\
\text { - } \text { Market Share }\end{array}$ \\
\hline
\end{tabular}

Figure 1: Conceptual Framework

Source: Primary Data

\subsection{Methodology and Design}

This study utilized cross-sectional descriptive survey research design of deposit taking SACCOs. Cooper and Schindler (2014) argue that by adopting the descriptive survey design, the researcher was able to describe the variables of the study and develop predictive regression model for forecasting the dependent variable. This design has the benefit of containing current views or disciplines and presenting knowledge in a short amount of time, such as the interval expected for distributing the survey and gathering the information. This design affords a quantitative 
or numeric description of trends, attitudes, or feelings of a population by examining a sample of that population. From sample results, the researcher concludes or draws inferences to the group (Kotler \& Keller, 2011).

\subsection{Target Population}

The target population was 277 employees, which comprised of board of director, supervisory committee senior and middle management team from the branch network of deposit-taking SACCOs in Uasin Gishu County (Mwalimu National, Harambee, Kenya Police, Stima and Afya). The officials of these SACCOs were targeted because they were the ones who were conversant and constantly apply cost leadership strategy for performance of deposit taking SACCOs in the society. In addition, they were also the custodians of vital documents such as the member registers, which are crucial to this study. The target population was as summarized in Table 1

Table 1: Target Population

\begin{tabular}{lcccccc}
\hline SACCOs & Mwalimu & Harambee & Kenya Police & Stima & Afya & Sub-total \\
\hline Board of Directors & 9 & 11 & 9 & 9 & 9 & $\mathbf{4 7}$ \\
Supervisory Committee & 3 & 3 & 3 & 3 & 3 & $\mathbf{1 5}$ \\
Senior Management & 17 & 21 & 12 & 11 & 11 & $\mathbf{7 2}$ \\
Middle Management & 35 & 35 & 26 & 28 & 19 & $\mathbf{1 4 3}$ \\
\hline TOTAL & $\mathbf{6 4}$ & $\mathbf{7 0}$ & $\mathbf{5 0}$ & $\mathbf{5 1}$ & $\mathbf{4 2}$ & $\mathbf{2 7 7}$ \\
\hline
\end{tabular}

Source: Kenya Union of Savings and Credit Co-operatives 2021.

\subsection{Sampling Procedure and Techniques}

This study utilized stratified random sampling where five categories were selected to form strata. The researcher considered this method appropriate because it is administratively convenient and ensures inclusion of all targeted subgroups to be part of the sample (Saunders et. al., 2011). In determining the sample size, the study was informed by the formula suggested by Yamane (1967) which is expressed as:

$\mathrm{n}=\frac{N}{1+N\left(e^{2}\right)}$

Where

$\mathrm{N}=$ is the sample size,

$\mathrm{N}=$ is the target population and

$\mathrm{e}=$ is the level of precision (specifically $\pm 5 \%$ precision at $95 \%$ confidence level).

Stratified method was employed in this study because the population has several managerial levels that were used as strata. Stratified sampling is necessary when the study needs to group people in heterogeneous groups to get a representative sample. This led to producing a sample size of 164 respondents as shown in Table 2.

Table 2: Sample Size

\begin{tabular}{lcccccc}
\hline SACCOs & Mwalimu & Harambee & Kenya Police & Stima & Afya & Sub-total \\
\hline Board of Directors & 5 & 6 & 5 & 5 & 5 & $\mathbf{2 6}$ \\
Supervisory Committee & 2 & 2 & 2 & 3 & 2 & $\mathbf{1 1}$ \\
Senior Management & 10 & 12 & 7 & 7 & 6 & $\mathbf{4 2}$ \\
Middle Management & 21 & 21 & 16 & 16 & 11 & $\mathbf{8 5}$ \\
\hline TOTAL & $\mathbf{3 8}$ & $\mathbf{4 1}$ & $\mathbf{3 0}$ & $\mathbf{3 1}$ & $\mathbf{2 4}$ & $\mathbf{1 6 4}$ \\
\hline Source: Researcher $(2021)$ & & & & & &
\end{tabular}

Source: Researcher, (2021)

\subsection{Proposed Data Analysis Techniques and procedure}

Data analyzed with the help of SPSS (version 23); where both descriptive and inferential statistics were generated. Data that was analyzed using descriptive statistics included mean, and standard deviation. The correlation analysis and hypotheses testing on the study variables relationships were done at (5\% level of significance) in explaining the strength, magnitude, direction and nature of influences disclosed.

In endeavoring to test quantitative hypotheses, this study adopted a positivism philosophy. Positivists put more weight on analysis of paradigms and recognize that the only best method to measuring attributes of an event is by quantitative measurement (Creswell, 2016). The resultant simple regression equation that can be used to predict level of performance of deposit-taking SACCOs for a one standard deviation progress in cost leadership strategy (economies of scale reduced operational costs and cheap sourcing) can be expressed as:

PDTS $=\beta_{0}+\beta_{1} \mathrm{CS}+\beta_{2} \mathrm{ROC}+\beta_{3} \mathrm{ES}+\varepsilon$.

Where:

PDTS $=$ Performance of Deposit-Taking SACCOs

$\beta_{0}=y$-Intercept; Constant

$\beta_{1}, \beta_{2}$, and $\beta_{3}=$ Beta or the Slope Coefficient

$\mathrm{CS}=$ Cheap Sourcing

$\mathrm{ROC}=$ Reduced Operational Costs 
$\mathrm{ES}=$ Economies of Scale

$\varepsilon=$ Error Term

\subsection{Study Findings}

\subsubsection{Descriptive Statistics of the Study Variables}

Before proceeding with the inferential analysis of the data, it was healthy scrutinizing the common descriptive statistics of the study sample data. As regards this, descriptive analysis allowed the researcher to see patterns among data and make sense of it. The results then implied that; 1 to $1.8=$ Strongly Disagree, above 1.8 to $2.6=$ Disagree, above 2.6 to 3.4 = Undecided, above 3.4 to $4.2=$ Agree, and above 4.2 to $5.0=$ Strongly Agree. The following section presented the descriptive statistics of the study variable as per the research objectives.

\subsubsection{Cost Leadership Strategy}

Descriptive statistics were meant to describe and help the researcher review the overall drifts in the data, present perception of how diverse aggregates might be and present intuition into where one attainment holds in association with others. To achieve this objective, cost leadership strategy (economies of scale; reduced operational costs and cheap sourcing) five-point Likert summated scale was used in the analysis. The results, which included mean and standard deviation, were analyzed, summarized, and presented in table 3

Table 3: Cost Leadership Strategy

\begin{tabular}{lccc}
\hline & N & Mean & Std. Dev. \\
\hline Our SACCO charge lower price than our competitors & 136 & 3.929 & .91136 \\
Our SACCO refrain from incurring too many expenses from innovation or & 136 & 3.641 & .13624 \\
marketing & 136 & 3.629 & .9329 \\
Our SACCO has reduced labor input through automations & 136 & 3.427 & .9823 \\
Our SACCO minimizes its procurement costs & 136 & 3.526 & .9488 \\
Our SACCO has access to low cost raw materials than our competitors & 136 & 3.804 & .9204 \\
Our SACCO strive to reduce cost in administration activities & 136 & 3.951 & .9816 \\
Our SACCO conducts costing promotion activities & 136 & 4.126 & .8636 \\
Our SACCO outsource functions to control costs & 136 & 3.720 & .8927 \\
Our SACCO continuously exercise tight cost control and pay attention to details & 136 & 3.954 & .8925 \\
Our SACCO identify underperforming areas in order to cut costs & 136 & 4.126 & .9426 \\
Our SACCO focus on product design technique that economize on cost of materials & 136 & 3.925 & 9225 \\
Our SACCO minimizes on operational cost & 136 & 4.016 & .8263 \\
Our SACCO conducts costing of its labor & 136 & 4.114 & .9126 \\
Our SACCO conducts service costing & &
\end{tabular}

\section{Source: Field Data, 2021}

The statements that 'our SACCO outsource functions to control costs and our SACCO focus on product design technique that economize on cost of materials reported the highest mean score of 4.126 with standard deviations of .8636 and .9426 respectively. The statements that our SACCO conducts service costing and our SACCO conducts costing of its labor with the mean score of .4.114 and 4.016 respectively closely followed this. This has the implication that the SACCOs the respondents were of the opinion that the SACCOs take cost issues very seriously. Our SACCO minimizes its procurement costs statement and our SACCO has access to low cost raw materials than our competitors reported the lowest mean score of 3.427 and 3.526 respectively. It is important to notice that despite the above named statements reporting the lowest mean score, the mean score is still high and according to the key, tie score is within the agreed scale.

\subsubsection{Performance of Deposit Taking SACCOs}

Performance of deposit taking SACCOs was measured using eight statements relating to this variable in which they were rated in a five Likert scale. Descriptive statistics, which involved mean and standard deviation, were jointly employed to summarize the responses as presented in Table 4

\section{Table 1: Performance of Deposit Taking SACCOs}

\begin{tabular}{llll}
\hline & $\mathrm{N}$ & Mean & Std. Dev. \\
\hline Our SACCO market share is relatively higher than other SACCOs in the county. & 136 & 3.862 .9069 \\
Our SACCO enjoys higher profitability margin than its competitors & 136 & 3.764 .8981 \\
Our SACCOs delights in improved employees productivity than its rivals & 136 & 3.892 & .13681 \\
Our SACCOs membership has been on increase for the last three years. & 136 & 3.843 & .9806 \\
Our SACCOs enjoys operational efficiency than its contestants & 136 & 3.856 .9881 \\
Our SACCO enjoys improved customer satisfaction than its competitors & 136 & 3.866 & .9024 \\
Our SACCO enjoys a larger customer base than its competitors & 136 & 3.727 .8957 \\
There is consistent development of new products and services in our SACCOs because of & & & \\
improved customer retention. & & 3.819 .9270
\end{tabular}


The findings indicated, "Our SACCO market share was higher than other SACCOs in the county" $(\mathrm{M}=3.862$; $\mathrm{SD}=0.9069)$, and that their SACCOs highly enjoyed higher profitability margin than their competitors $(\mathrm{M}=3.764$; $\mathrm{SD}=0.8981)$. They indicated that their SACCOs highly delighted in improved employees' productivity than their rivals $(\mathrm{M}=3.892 ; \mathrm{SD}=0.13681)$ and that their SACCOs membership had been on high increase for the previous four years $(\mathrm{M}=3.843 ; \mathrm{SD}=0.9806)$. It was shown that their SACCOs highly enjoyed operational efficiency than its contestants $(\mathrm{M}=3.856 ; \mathrm{SD}=0.9881)$ while their $\mathrm{SACCO}$ highly enjoyed improved customer satisfaction than their competitors $(\mathrm{M}=3.866$; $\mathrm{SD}=0.9024)$ as the SACCO highly enjoyed a larger customer base than their competitors $(\mathrm{M}=3.727 ; \mathrm{SD}=0.8957)$ and that there was highly consistent development of new products and services in their SACCOs because of improved customer retention. $(\mathrm{M}=3.819$; $\mathrm{SD}=0.9270)$.

\subsection{Correlation Analysis}

Correlation analysis was performed, using Pearson Product Method (PPM) at 5\% (0.05) level of significance to establish whether there existed relationship between the dependent variable and each independent variable. Correlation analysis of all the independent variables was determined to express their association with the dependent variable (performance of deposit taking SACCOs) that is to infer features of populations grounded on samples (Johnson \& Christensen, 2014). The independent variables (cheap sourcing, reduced operational costs, and economies of scale) were correlated with the dependent variable of the study (performance of deposit taking SACCOs) and results shown in Table 6.

\section{Table 6: Cost Leadership Strategy and Performance of Deposit Taking SACCOs}

\begin{tabular}{|c|c|c|c|c|c|}
\hline & & 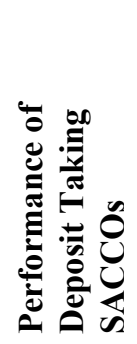 & 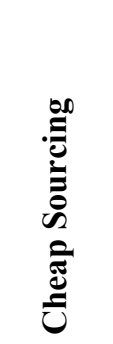 & 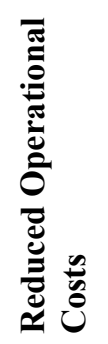 & 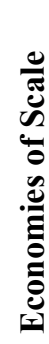 \\
\hline Performance of Deposit Taking SACCOs & Pearson Correlation & 1 & & & \\
\hline Cheap Sourcing & $\begin{array}{l}\text { Pearson Correlation } \\
\text { Sig. (2-tailed) } \\
\text { N }\end{array}$ & $\begin{array}{c}.442 * \\
.000 \\
136\end{array}$ & 1 & & \\
\hline Reduced Operational Costs & $\begin{array}{l}\text { Pearson Correlation } \\
\text { Sig. (2-tailed) } \\
\text { N }\end{array}$ & $\begin{array}{c}.754 * * \\
.000 \\
136\end{array}$ & $\begin{array}{l}.724 * \\
.000 \\
136\end{array}$ & 1 & \\
\hline Economies of Scale & $\begin{array}{l}\text { Pearson Correlation } \\
\text { Sig. (2-tailed) } \\
\text { N }\end{array}$ & $\begin{array}{l}.732 * \\
.000 \\
136\end{array}$ & $\begin{array}{c}.687 * * \\
.000 \\
136\end{array}$ & $\begin{array}{l}.747^{*} \\
.000 \\
136\end{array}$ & 1 \\
\hline
\end{tabular}

*. Correlation is significant at the 0.05 level (2-tailed).

**. Correlation is significant at the 0.01 level (2-tailed).

Source: Field Data, 2021

The study results indicated that the highest statistically significant positive correlation was reported between the reduced operational costs and performance of deposit taking SACCOs $(r=.754, p<.01)$. This was closely followed by the association between economics of scale and performance of deposit taking SACCOs $(r=.732, p$ $<.05)$. The lowest and positive association was reported between cheap sourcing and performance of deposit taking SACCOs $(\mathrm{r}=.442, \mathrm{p}<.05)$. All the indicators of cost leadership strategy (cheap sourcing, reduced operational costs, and economies of scale) had statistically significant positive correlation with the highest correlation reported between reduced operational costs and economies of scale $(r=.747, p<.05)$. This meant that they were all moving in the same direction.

\subsection{Regression Analysis and Hypotheses Testing}

The study intended to establish the influence of cost leadership strategy on performance of deposit-taking SACCOs as stated below;

$\boldsymbol{H}_{01}$ : There is no statistically significant influence between cost leadership strategy and performance of deposit-taking SACCOs in Uasin Gishu County, Kenya.

In order to establish the influence of cost leadership strategy (economies of scale, reduced operational costs, cheap sourcing) on performance of deposit-taking SACCOs, and be able to test the hypothesis, the mean score of cost leadership strategy parameters (economies of scale reduced operational costs, and cheap sourcing) were 
regressed on the aggregate mean score of performance of deposit-taking SACCOs (dependent variable) and the relevant research results presented in Tables 7, 8, and 9.

Table 7: Results for Cost Leadership Strategy and Performance of Deposit Taking SACCOs

Model Summary

\begin{tabular}{ccccc}
\hline Model & R & R Square & Adjusted R Square & Std. Error of the Estimate \\
\hline 1 & $.824^{\mathrm{a}}$ & .678 & .634 & .72473
\end{tabular}

a. Predictors: (Constant). Cheap Sourcing, Reduced Operational Costs, Economies of Scale

Table 8: Cost Leadership Strategy and performance of Deposit-taking SACCOs ANOVA ${ }^{\mathrm{a}}$

\begin{tabular}{llccccc}
\hline Model & & Sum of Squares & Df & Mean Square & F & Sig. \\
\hline \multirow{2}{*}{1} & Regression & 6.007 & 3 & 2.002 & 9.862 & $.002^{\mathrm{b}}$ \\
& Residual & 19.044 & 132 & .203 & & \\
& Total & 25.051 & 135 & & & \\
\hline
\end{tabular}

a. Dependent Variable: Performance of Deposit-Taking SACCOs

b. Predictors: (Constant), Cheap Sourcing, Reduced Operational Costs and Economies of Scale

Table 9: Cost Leadership Strategy and Performance of Deposit-Taking SACCOs

\begin{tabular}{|c|c|c|c|c|c|c|}
\hline \multirow{2}{*}{\multicolumn{2}{|c|}{ Model }} & \multirow{2}{*}{\multicolumn{2}{|c|}{$\begin{array}{l}\text { Unstandardized } \\
\text { Coefficients }\end{array}$}} & \multirow{2}{*}{$\begin{array}{c}\text { Standardized } \\
\text { Coefficients } \\
\text { Beta } \\
\end{array}$} & \multirow[t]{2}{*}{$\mathbf{T}$} & \multirow[t]{2}{*}{ Sig. } \\
\hline & & & & & & \\
\hline \multirow{4}{*}{1} & (Constant) & 5.166 & 439 & & 11768 & 000 \\
\hline & Cheap Sourcing & .465 & .108 & .324 & 4.305 & .002 \\
\hline & Reduced Operational Costs & .634 & .231 & .432 & 2.745 & .000 \\
\hline & Economies of Scale & .654 & .264 & .521 & 2.477 & .000 \\
\hline
\end{tabular}

a. Dependent Variable: Performance of Deposit-Taking SACCOs

Source: Field Data, (2021)

Model summary (Table 7) results established that cost leadership strategy had a positive relationship with performance of deposit-taking SACCOs $(\mathrm{R}=.824)$. Cost leadership strategy (economies of scale reduced operational costs, and cheap sourcing) had explanatory power over performance of deposit-taking SACCOs because it accounted for 67.8 percent of performance of deposit-taking SACCOs variation $(\mathrm{R}$ square $=.678)$. The research results coincides with Marangu, Mwiti and Thoronjo (2017) who did a study on the influence of cost leadership on the organizations' competitiveness of sugar firms in Kenya. The study covered all the sugar firms in Kenya with a target population of one hundred and ninety manage and a sample size of one hundred and twenty seven of them. The research found out that cost leadership strategy had an influence on organizations' competitiveness and accounted for 68.7 percent of organizations' competitiveness of sugar firms' change (R square $=.687)$.

The ANOVA (Table 8) results showed that the F-value was more than $1(\mathrm{~F}=9.862, \mathrm{P}$-value $=.002)$. Since the results of the F-value in overall ANOVA were significant; then the implication was that the prediction capacity of the model contribution to performance of deposit-taking SACCOs. This means that this model can meaningfully forecast the variation in performance of deposit-taking SACCOs.

The coefficients results (Table 9) showed that cost leadership strategy (economies of scale, reduced operational costs, and cheap sourcing) was an important contributor to coefficient model of performance of deposit-taking SACCOs $(t=11.758, \mathrm{p}=.000<.05)$. The study coefficients results exposed a statistically significant positive influence of cost leadership (economies of scale reduced operational costs, and cheap sourcing) on performance of deposit-taking SACCOs $(\beta=.465, .634$. and.654 respectively.

The influence was found to be significant since $p$-value was less than $.05(\mathrm{p}-$ value $=.002)$. The hypotheses testing criteria was that reject hypothesis one if $p$-value is less than .05 and $\beta \neq 0$ or else do not reject $\mathrm{H}_{01}$ in case $p$-value $>.05$. Based on the study results, $\beta s \neq 0$ and $p$-values $<.05$, the study rejected hypothesis and stated that there was a statistically significant influence of cost leadership (economies of scale reduced operational costs, and cheap sourcing) on performance of deposit-taking SACCOs in Uasin Gishu County.

The resultant simple regression equation that can be used to predict level of performance of deposit-taking SACCOs for a one standard deviation progress in cost leadership strategy (economies of scale reduced operational costs and cheap sourcing) can be expressed as:

$\mathrm{PDTS}=5.166+.465 \mathrm{CS}+.634 \mathrm{ROC}+.654 \mathrm{ES}+\varepsilon$.

Where:

PDTS $=$ Performance of Deposit-Taking SACCOs

$5.166=\mathrm{y}$-Intercept; Constant 


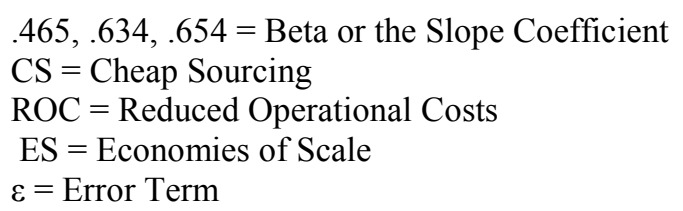

The unstandardized beta coefficient $.465, .634, .654$ denotes the anticipated enhancement in performance of deposit-taking SACCOs for a unit standard deviation improvement in economies of scale reduced operational costs and cheap sourcing respectively. This means that, holding other factors constant, one standard deviance improvement in economies of scale reduced operational costs and cheap sourcing would increase the level of performance of deposit-taking SACCOs by a factor of approximately $.465, .634$ and .654 respectively.

\subsection{Discussion on the Study Results}

The correlation study outcomes indicated that cost leadership strategy had a positive relationship with performance of deposit-taking SACCOs $(\mathrm{R}=.824)$. Cost leadership strategy (economies of scale reduced operational costs, and cheap sourcing) had explanatory power over performance of deposit-taking SACCOs because it accounted for 67.8 percent of performance of deposit-taking SACCOs variation (R square $=.678)$. This implies that 32.2 percent of change in performance of deposit-taking SACCOs can be accounted for by other factors other than cost leadership strategy $(1-.678=.32 .2)$. The finding of the study greatly contradicted the null hypothesis that cost leadership strategy has no significant influence on performance of deposit taking SACCOs.

These findings agree with various scholars such as Marangu, Mwiti and Thoronjo (2017) who did a study on the influence of cost leadership on the organizations' competitiveness of sugar firms in Kenya. The study covered all the sugar firms in Kenya with a target population of one hundred and ninety manage and a sample size of one hundred and twenty seven of them. The analysis found out that cost leadership strategy had an influence on organizations' competitiveness and accounted for 68.7 percent of organizations' competitiveness of sugar firms' change $(\mathrm{R}$ square $=.687)$. The research concluded that cost leadership strategy had a significant influence on the organizations' competitiveness of the sugar firms. The study recommended that sugar firms should make more efforts in engaging cost leadership in their operations aiming at achieving more organizations' competitiveness.

\subsection{Summary of the Findings}

The study established there is a statistically significant positive influence of constructs of cost leadership strategy (economies of scale, reduced operational costs, and cheap sourcing) on performance of deposit-taking SACCOs $(\mathrm{p}<0.05 ; \mathrm{R} 2=0.678)$. To improve performance, the low-cost strategy should be highly practiced among the DTSACCOs in Uasin Gishu County where these DT-SACCOs should seek to emphasize cost reduction through cutting down on major expenses especially on innovation, operations, labour, and marketing as they also drastically reduce wastages. These DT-SACCOs should also cut costs on procurement, source cheaper raw materials, and cut on administration activities costs. All costs on promotion activities and outsourcing functions should be reduced accordingly as the DT-SACCOs engage in a proficient continuous improvement exercise and paying attention to details. Then all underperforming areas should be managed effectively. Thus, performance is enhanced by necessitating that the business operates at the lowest cost through aggressive pursuit of cost reduction, tight cost, and overhead management while importantly ensuring that they provide products and services that customer's value.

\subsection{Conclusion}

The study concludes that cost leadership strategy, a Porter's generic strategy used in wide (broad) market, can significantly help improve performance of deposit-taking SACCOs since it had significant influence on performance of deposit-taking SACCOs. As a result, implementing a low-cost strategy entails an active pursuit of cost reduction, tight cost and overhead control, and cost minimization, all of which are important for spurring performance in DT-SACCOs.

\subsection{Recommendation}

The study concluded that cost leadership strategy (cheap sourcing, reduced operational costs and economies of scale) had a significant influence on performance of deposit taking SACCOs in Uasin Gishu County. The study therefore recommended that SACCO officials in Uasin Gishu County should make more attempts in applying cost leadership strategies in order to enhance performance of deposit taking SACCOs.

\section{References}

Achieng', B. S. \& Ngala, M. O. (2019). Effect of cost leadership on the performance of smes in Nakuru, central business district, The International Journal of Humanities \& Social Studies

Allen, R., \& Helms, M. (2006). Methods of Inclusion and Application Use in Manufacturing Techniques. Business 
Process Management, 12 (4), 433-454.

Barney, J. B., (2011). Management and Competition System: Tips and Concerns. Expensive Stock Cost Pearson Prentis Hall, Inc.

Barney, J.B. (2007) .Find and Save Competitions, Third Edition, Pearson Education, New Jersey, USA

Buul, O. B. \& Omundi, R. (2017) an analysis of competitive strategies and performance of small and medium enterprises in Kenya: A case of Nairobi central business district. Journal of Business and Strategic Management, 2(2), 72 - 94, 2017

Cooper, C.R., \& Schindler, P.S., (2014). Commercial Research Methods (December 12). Boston: McGraw-Hill World Edition.

Creswell, J. W. (2016). Introduction to the Study of Mixed Methods. Sage Publishing: Michigan USA. Consumer Organizations. International Journal of Business and Social Sciences, 3, 24.

Gure, A. K. \& Karugu, J. (2018). Strategic management practices and performance of small and micro enterprises in Nairobi City County, Kenya. International Academic Journal of Human Resource and Business Administration, 3(1), 1-26.

Johnson, B. \& Christensen, L. (2014). Academic Research: Scale, Quality and Method of Inclusion. (Editor 2). Boston, Ma: Pearson, Inc.

Johnson, G, \& Scholes, K. (2011). Institutional Review, Englewood Cliffs, NJ. In Front of the Hall.

Johnson, G. \& Scholes, K. (2012). Technology in This Industry. Anode and Category Catalog Journal.

Mandara M. O. (2014). Generic competitive business strategies and performance of micro and small enterprises in Nairobi: An empirical validation of the MSE Typology (Doctoral Thesis, University of Nairobi).

Onyonyi, A. O. (2018). Effect of Competitive Strategies on Growth of Small and Medium Enterprises in Kenya Funded by Women Enterprise Fund (Doctoral Thesis, Jomo Kenyatta University of Agriculture and Technology)

Porter, M. (1985). Competitive advantage: Creating and sustaining superior performance. New York: Free Press.

Porter, M. (2012). Process in a Difficult World: Creating Value. Porter India Boston, Ma / New Delhi,

Porter, M.E., \& Kramer, M.R. (2011). Creating shared value. Harvard business review, 89(1/2), 62-77.

Saunders, M., Lewis, P. \& Thornhill, A. (2009). Business Student Research Methods (5th Ed.). Harlow: Prentice Hall.

Sumer, K., \& Bayraktar, C. A. (2012). Business Trends and Porter Style Failures: A Book Review. Management Research Journal, 4 (3), 100-119 